\title{
THE EFFECT OF LEADER SUPPORT AND COMPETENCE TO THE ORGANIZATIONAL COMMITMENTS ON EMPLOYEES PERFORMANCE OF HUMAN RESOURCES DEVELOPMENT AGENCY IN WEST KALIMANTAN
}

\author{
Raziki Waldan* \\ IAIN Pontianak, Indonesia
}

\begin{abstract}
The performance on employees of Human Resources Development Agency in West Kalimantan can be said to be not optimal when viewed from the accuracy of their internal reporting The results of this study can be concluded: 1) there is an influence of leader support on organizational commitment of employees of the Human Resource Development Agency in West Kalimantan. It can be proven empirically that the higher the suitability between the leader's support and its members, it will increase organizational commitment to employees; 2) there is the influence of leaders' support on the performance of employees of the Human Resources Development Agency in West Kalimantan; 3) there is an influence of competence on organizational commitment of employees of the Human Resource Development in West Kalimantan. This is the higher competence of employees, the higher the commitment of employees of the human resource development in West Kalimantan. There is the influence of competence on the performance of employees of the Human Resource Development Agency in West Kalimantan; 4) there is an organizational influence on the performance of employees of the Human Resources Development Agency in West Kalimantan.
\end{abstract}

JEL : M10, O15.

Keywords : leader support, competence, organizational commitment, employee performance.

\section{INTRODUCTION}

Human resources are one of the spearheads of the organization. Without human resources, all resources owned by the company cannot be managed and developed. Every organization, including government organizations, needs human resources with the performance of competent and professional employees to produce good output for the organization. Employee performance needs to be considered by leaders because its performance is directly related to improving the quality of the organization. Employee performance is a complex process, both from employees (internal factors) and the company's strategic efforts. Good performance is, of course, an expectation for all companies and institutions that employ employees, because the performance of these employees is ultimately expected to improve the overall quality of the company. Factors that can influence the improvement of employee performance such as leadership support, competence, and organizational commitment (Waldan, 2017; Mailisa, Hendri, \& Fauzan, 2016; Hendri \& Ramadhania, 2010; Yustina, 2018).

Organizational commitment is the extent to which someone identifies himself as part of the organization and wants to continue active participation in it. Organizational commitment can also be seen as a situation where an employee or individual has integrity towards the

\footnotetext{
*Email : zikysmart@gmail.com

Received : 31-05-2019, Accepted : 26-06-2019, Published : 28-04-2020.

P-ISSN : 2087-9954, E-ISSN : 2550-0066. DOI : http://dx.doi.org/10.26418/jebik.v9i1.33150
} 
organization and intends to maintain membership in the organization. Thus, high organizational commitment shows the level of employee bias towards the organization that employs it. Pella, Sumarman, Arief, \& Kirbradoko (2013), Anang (2016), Supriyadi (2010) research found that organizational commitment is positively related to employee performance.

Competence is the ability to carry out work or tasks based on skills and knowledge supported by work attitudes demanded by work (Ristyawan, 2016). Competence can increase organizational commitment and employee performance. Through the skills and knowledge possessed by employees, employees become more enjoying all work processes and feel that the work is part of their lives indirectly employees feel they have the organization where they work. Knowledge and skills of employees also produce a satisfactory performance for the organization (Waldan, 2017; Wheeler, Foster, \& Hapburn, 2013; Rokhman, Rivai, \& Abidin, 2011).

From the explanation above, it can be seen that performance, organizational commitment, competence and leader support are interrelated. Performance improvements are not only needed by private organizations but also in government organizations, including the Human Resources Development Agency in West Kalimantan. The performance of employees of the Human Resources Development Agency in West Kalimantan can be said to be not optimal when viewed from the accuracy of their internal reporting. The accuracy of reporting can be seen in the table as follows:

Table 1. Attendance Recapitulation of Employees of Human Resource Development in West Kalimantan

\begin{tabular}{cccccc}
\hline Number & Year & Number of employees & Present & Absent & \% Presence \\
\hline $\mathbf{1}$ & $\mathbf{2}$ & $\mathbf{3}$ & $\mathbf{4}$ & $\mathbf{5 = 3 - 4}$ & $\mathbf{6 = 4 : 3 \times 1 0 0}$ \\
\hline 1 & 2014 & 82 & 79 & 3 & 96,34 \\
2 & 2015 & 82 & 76 & 6 & 92,68 \\
3 & 2016 & 82 & 80 & 2 & 97,56 \\
\hline
\end{tabular}

Source: Human Resources Development Agency in West Kalimantan, 2019

From the table, it can be seen that in 2014 the percentage of employee attendance was $96.34 \%$, but in 2015 the attendance rate was 92.68\%. In 2016, employee attendance rates again increased by a percentage of $97.56 \%$. Poor performance occurs due to several factors, one of which is leader support. A leader must be able to manage resources effectively and efficiently, especially in the management of his subordinates. In conditions like this, leaders are required to always have a new strategy to be able to develop and maintain capable employees needed by an agency. For this reason, leaders need support for employees to be able to work professionally and with integrity. Leader support also influences the success of implementing a new system and developing innovative subordinate strengths.

Leader support is a situation where individuals receive special attention from their managers or leaders. This shows that subordinates who get attention from the leader means that they have received support from the leader (Prabu, 2016). Based on the background above, the author feels interested in examining "The Effect of Leader Support and Competence on Organizational Commitment and Its Impact on the Employee Performance of the Human Resource Development Agency in West Kalimantan ". 


\section{LITERATURE REVIEW}

\subsection{Leader Support}

A work environment characterized by support from leaders will determine effective performance improvements (Sulaefi, 2017). This means that managers and leaders who give attention and welfare, personal motivation will have a positive impact on the success of the process of improving performance. Leaders must support and encourage the realization of new skills and knowledge that will determine effective performance improvements. Supporting leaders play a role in the extent to which employees can transfer what they get in training to their jobs.

Leader support is a situation where individuals receive special attention from their managers or leaders. This shows that subordinates who receive training from leaders mean they have received support from the leader (Anang, 2016). It can be concluded that leader support is the extent to which leaders provide encouragement and motivation to their employees in increasing their potential and applying the ability of employees to the workplace. Leader support is defined as the extent to which leaders encourage participation in training, innovation, and acquisition of knowledge and provide recognition to employees involved in activities (Prabu, 2016).

Leader support produces a compulsory feeling for employees to help the organization achieve its goals, increase commitment to the organization and hope that high performance will be noted and valued. Leader support also generates feelings for employees to maintain the welfare of the organization manifested in the form of actions that can help the organization achieve its goals. Leader support is influenced by the experiences that individuals have, as well as observations about the daily lives of organizations in treating someone. In this case the leader's attitude towards the ideas put forward by the employee, the response to the employee who experiences the problem and the company's attention to the welfare and health of the employee are three aspects that are the main concern of the employee.

Employees expect leaders to provide support so that everyone can work optimally to achieve common goals. Leader support is the employee's perception that he is valued and cared for by the organization or company where he works. When leaders pay attention to and appreciate the efforts made by individuals to achieve company goals, individuals will feel that leaders provide support to them. Robbins (2016) states that indicators of leader support are: (1) give advice and encouragement to attend training; (2) rncourage participation in training, innovation, and increasing knowledge; (3) giving recognition to employees involved in this activity.

The results of Ismail, Alam, \& Roshanti (2017) show that support from leaders and supervisors for the application of new skills and knowledge will encourage individuals to apply them in their work. Research conducted by Michell, Steward, \& Bruce (2009) shows that the transfer of new skills into work is determined by the support of the leader. According to Hendri \& Ramadhania (2010) in many studies, it was also found that the success of the stages in the performance improvement process was influenced by the characteristics of the work environment (organizational support) such as leadership support, other employee support, technology support, and the development of his expertise. 
The theory used in leader support is namely the theory of Leader-Member Exchange (LMX). LMX is a theory that explains how interpersonal relationships develop between leaders and subordinates. LMX is a process of interaction that occurs in two individuals and will continue to develop (Supriyadi, 2010). The concept of leader and subordinate exchange, otherwise known as the exchange of foreign leader members (LMX), is a relationship that relates between the nature of leaders and employees, which Dansereau later added. And finally, they have determined the roles that must be filled by each party and continue to be connected.

It is important to pay attention to the differences in meanings and descriptions in the leadership literature between leaders and managers. A manager is responsible for ensuring that daily operations run smoothly, while leaders are responsible for ensuring that the organization goes in the right direction. In other words, leaders are usually regarded as visionaries in an organization. Leaders usually operate at a high level, dare to take risks, try to develop new ideas and new directions for the organization. Instead, managers are usually involved in day-to-day coordination activities that allow the organization to operate properly.

LMX theory reveals interpersonal relationships that involve support from leaders to subordinates within the framework of a formal organization. Leader-member exchange can be defined as an exchange relationship based on competence, interpersonal skills, and trust. Furthermore, understanding the exchange relationships that occur between coworkers is an important part of understanding how the leadership process works. However, many exchange relationships are ignored in research, this can be seen from the very limited empirical research conducted.

\subsection{Competence}

Competence is the ability to carry out or carry out work based on skills and knowledge supported by work attitudes demanded by work (Sulaefi, 2017), Thus competence shows skills or knowledge that are characterized by professionalism in a particular field and applied to increase agreed benefits. Competence also shows the characteristics of the knowledge and skills possessed or needed by each individual that enables them to carry out their duties and responsibilities effectively and improve professional quality standards in their work. Competence explains what people do at work at various levels and details the standards of each level, identifying the characteristics of knowledge and skills needed by individuals that enable them to carry out their duties and responsibilities effectively in achieving professional quality standards in the workplace.

According to Mahmud \& Schölmerich (2011), Competence is a behavioral dimension behind the competent performance that shows how people behave when they perform their roles well. Ristyawan (2016) competence is a basic characteristic of personnel which is a determining factor for a person's success in working at a job or in certain situations. Hendri \& Ramadhania (2010) also explained that competence is a picture of what someone must know or do to do their job well. Components that shape competence according to Robbins (2006) are: (1) knowledge; (2) skills; (3) self-concept; (4) characteristics; (5) motives.

Hendri \& Ramadhania (2010) states that competence is the basic foundation of people's characteristics and shows how to behave or think, equate situations, and support for long periods. There are 5 (five) characteristics of competencies or components, namely: (1) motives are things that are consistently thought or desired by people that cause motive actions to encourage, direct 
and choose behaviors towards certain actions or goals; (2) nature is a characteristic response and is consistent with the situation and information; (3) self-concept is the attitude, values or selfimage of a person, self-confidence is the belief of people that they can be effective, in almost every situation is part of everyone's self-concept; (4) knowledge is information that people have in a particular field, knowledge is a complex competency, scores on knowledge tests often fail to predict job performance because they fail to measure knowledge and skills in ways that are used in work; (5) skills are the ability to perform certain physical or mental tasks, mental competence or cognitive skills including analytical and conceptual thinking.

\subsection{Organizational Commitments}

Organizational commitment is a personal value, which often refers to company loyalty or commitment to the company (Rokhman et al., 2011). The concept of organizational commitment arises from studies that explore relationships/relationships between employees and people. Motivation to conduct organizational commitment studies is based on the belief that employees who are committed to the organization will benefit the company because of their potential abilities and reduce turnover and improve performance. Organizational commitment as a tendency or tendency to commit to consistent lines and activities. Organizational commitment as a condition in which an employee sided with a particular company or organization and on the goals of the organization and intended to maintain membership in the organization (Cohen, Angela, \& Leung, 2009).

Organizational commitment is the desired quality that must be maintained among employees. In this case, things must be seen that can affect one's organizational commitment. Cohen et al. (2009) identifies several factors which are then summarized in 4 categories: (1) personal factors, where general organizational commitment is greater between employees who are old and old working in organizations. Those who have intrinsic work values have more organizational commitment. In groups, female employees tend to be more committed to the company than male employees. Low-educated employees tend to have higher commitments than highly educated employees; (2) role characteristics, where organizational commitment will tend to be stronger for employees who have enriched jobs and jobs that involve low levels of role conflict and ambiguity; (3) structural characteristics, organizational commitment will be stronger in employees who are in a decentralized organization and in cooperation between work owners where employees are more involved in making organizational decisions; (4) work experience, organizational commitment will be strong for employees with pleasant work experience, such as a positive attitude in a group of people towards others, a feeling that an organization can be relied upon to fulfill its organizational commitment to personnel in it and the feeling that individuals in the organization are which is important for the organization.

Ismail et al. (2017) states that organizational commitment must be seen strategically for the company. Therefore, many companies spend time, energy, and funds to explore organizational commitments related to their activities. Companies need initial identification of what their workers need. Companies should not assume that all their workforce at all levels has the same needs. Employee commitment can be a reflection of socio-economic or cultural influences. states that past research and recent research support the influence of organizational commitment on desired outcomes, such as performance and negatively affect the desire to move and lose a job. 
Organizational commitment consists of three factors, namely a strong desire to remain a member of the organization, a great willingness to strive for the organization, and strong trust and acceptance of the values and goals of the organization. These three characteristics state that organizational commitment involves more than just passive loyalty to the organization. This involves an active relationship with the organization, where employees can give themselves and make a personal contribution to help the organization achieve success (Pella et al., 2013).

In their review of the literature on organizational commitment, Michell et al. (2009) explained three forms of organizational commitment, namely: (1) affective commitment is defined as the degree to which an individual is psychologically bound to the organization that employs through feelings such as loyalty, bound and agreed with organizational goals. Thus, the effective organizational commitment of an individual is related to the emotional bond or identification of the individual with the organization; (2) continuance commitment refers to an awareness of the costs associated with leaving the organization. Continuous commitment is a situation where employees feel the need to stay, where they think that leaving the company will be very detrimental to them. In other words, individuals with high organizational commitment will survive in the organization because they need it; (3) normative commitment is a feeling of an employee about the obligation to stay in the organization. In this case, according to Brahmana, Brahmana, \& Theresa (2018) normative organizational commitment is characterized by the conviction of employees that he is obliged to live or survive in a particular organization because of personal loyalty. In other words, employees with high normative organizational commitment will survive in the organization because they have to do so.

\subsection{Employees Performance}

Performance has the origin of the word "work". Work means activities carried out by a person or organization in carrying out their duties which are their work. While the term performance itself comes from the word "work performance" or actual performance, namely the actual performance or achievement achieved by someone in carrying out the task following the responsibilities given to him (Krysik \& Finn, 2010). Performance has meaning as action, achievement, or general appearance of the skills possessed (Arifin, Firmansyah, \& Fontana, 2015). This means that performance can be said as an action and achievement as well as the skills shown by someone in carrying out their actions or work.

Robbins (2016) states that performance is the result of evaluating the work carried out compared to predetermined criteria. Performance is a term that is often heard and associated with the activities of a person or organization in carrying out activities to achieve its objectives. During this time, the performance was interpreted and defined by various perspectives by many experts. Interpretation depends on what context and where the definition of performance is placed. Krysik \& Finn (2010) suggests that performance is the level of success of a person in carrying out his work duties.

Michell et al. (2009) describes the performance as a behavior that increases in certain periods or moments, is the subject itself, where performance is often directed as an index of something else, such as lessons and encouragement. According to Supriyadi (2010) performance is the expected result of each work behavior. in other words, performance is the appearance of a person's ability to do work that can be seen or observed from his behavior at work. Performance is the appearance of something or what is produced by someone in his workplace behavior. To be 
able to do work, one must combine abilities, efforts, and opportunities that can be assessed from the results of his work.

Employee performance is the result achieved by workers in their work according to certain criteria that apply to a particular job. Robbins (2006) states that employee performance is a function of the interaction between ability and motivation. Ismail et al. (2017) states that the purpose of setting performance goals is to set goals that are useful not only for performance evaluation at the end of the period but also for managing the work process during that period. Elmuti (2013) states that employee performance is a person's success in carrying out a job. Performance is the work of an employee for a certain period.

According to Robbins (2006) the criteria used to assess employee performance are as follows: (1) quality, namely the results of activities carried out near perfect, in the sense of adjusting some of the ideal ways of performing activities in meeting the expected objectives of an activity: (2) quantity, namely the number or target produced is expressed in terms of units the number of cycles of activity completed; (3) knowledge and skills, namely knowledge and skills possessed by employees of an organization; (4) communication, namely the relationship or interaction with co-workers in the organization. From this explanation, it can be concluded that the benchmark for measuring employee performance is quality, quantity, knowledge and skills, and communication.

\subsection{Leader Support, Competence, Organizational Commitments, and Employees Performance}

Research conducted by Prabu (2016) entitled "Pengaruh Penghargaan dan Motivasi Terhadap Kinerja Karyawan (Studi Pada Divisi Penjualan PT. United Motors Center Suzuki Ahmad Yani, Surabaya" with the studied variables of growth and profitability, performance, turnover, job satisfaction, and quality of work life. Samples from the best companies represent companies with high quality of life practices while companies in the S\&P 100 are used as a control group for comparison purposes. The findings in their empirical study found that companies with high-quality work practices will enjoy high growth (as measured by asset growth and sales for 5 years) and also profits (measured by ROA and ROE for 5 years). However, this research shows that there is no significant effect between the quality of work-life and employee job satisfaction.

The research conducted by Pella et al. (2013) entitle "The Determinant Factors of Technology Adoption for Improving Firm's Performance: An Empirical Research of Indonesia's Electricity Company. Using the regression analysis method, Arifin et al. (2015) observed the impact of the Tecnology Adoption on the Firm`s Performance showing a positive relationship between the three variables. The self-managed work team itself is another form of Firm's Performance which in essence is to provide opportunities for workers to participate in problemsolving, give authority to act and make decisions related to their work. This study uses a questionnaire adapted from the Michigan Organizational Assessment Package, there are 8 measured variables, namely suggestion offered, participation in decision making, workgroup communication, meaning, challenge, personal responsibility, accomplishment, and advancement. The analytical tool used is a linear regression technique showing a positive relationship between quality of work-life, performance, and internet aided self-managed teams. The performance measured here is not only business performance but also employee performance, this is indicated 
by the increasing percentage of time spent in actual production and the increased quality of the products produced.

Quality of work life has a significant effect on performance not only proven by research (Arifin et al., 2015) . The same thing has been proven by other studies, as in Michell et al. (2009) entitled " Comprehensive Analysis of Marketing Journal Rankings". Compared 88 companies that were identified as the best companies in America with 88 companies belonging to the Standard and Poor's one Hundred (S\&P 100) whose results showed that high-quality work-life practices would be directly proportional to the performance of its employees.

Brahmana et al. (2018) conducted a study entitled "Training and Development Policy, Corporate Governance, and Firm Performance with variables namely job satisfaction and performance. This research was conducted with Training and Development Policy, Corporate Governance, and Firm Performance. The results of the study found a positive effect on overall job satisfaction both in terms of satisfaction with the job itself, the relationship at work, payment, promotional opportunities, and nurses working conditions on performance.

Based on theoretical studies and previous research, the hypotheses in this study are as follows:

1. Hypothesis $1(\mathrm{H} 1)$ is "There is an influence of superiors' support on the organizational commitment of employees of Human Resources Development Agency in West Kalimantan".

2. Hypothesis $2(\mathrm{H} 2)$ is "There is an influence of superiors' support on the performance of employees of Human Resources Development Agency in West Kalimantan".

3. Hypothesis $3(\mathrm{H} 3)$ is "There is an influence of competence on the organizational commitment of Human Resources Development Agency in West Kalimantan".

4. Hypothesis $4(\mathrm{H} 4)$ is "There is an influence of competence on the performance of employees of Human Resources Development Agency in West Kalimantan".

5. Hypothesis 5 (H5) is "There is an influence of organizational commitment to the performance of Human Resources Development Agency in West Kalimantan".

\section{RESEARCH METHODS}

The research approach used in this study uses a quantitative approach, which emphasizes numerical data (numbers) processed by statistical methods so that the significance of the relationship between the variables studied will be obtained. This study aims to obtain evidence of a causal relationship (causal) between independent variables namely superiors' support (X1), competence (X2), intermediate variables namely organizational commitment (Y1), and the dependent variable is performance (Y2). This research is population research, so that all populations are sampled. In this study, the population was 82 employees of the Human Resources Development Agency in West Kalimantan.

Data collection techniques used in this study were observation, questionnaires and unstructured interviews. The questionnaire in this study was measured using a Likert measurement scale with alternative answers strongly agreed given a score of five, agreed given a score of four, neutral given a score of three, disagreeing given a score of two and strongly disagreeing given a score of one. Data analysis techniques in this study consisted of frequency distribution, average statistics, validity and reliability tests, classic assumptions and multiple 
linear regression with the help of SPSS 15.0 software. Based on the validity test shows the results that all indicators have values above 0.2319 , so it can be concluded that all indicator variables are valid and are considered good. The reliability test uses the Cronbach alpha $(\alpha)$ calculation technique. The reliability test results show that the Cronbach alpha value of each variable is greater than 0.60 so that it can be said that all statement items on each variable are reliable.

\section{RESULT AND DISCUSSION}

The normality test results obtained asymptotic significance (for two-way tests) of 0.985 . Because sig > alpha (0.05) then accept H0 means: Residual regression is normally distributed. Based on the results of an examination of linearity assumptions above, it can be seen that the relationship between the variables of leader support, competence, and organizational commitment is linear because the significance of linearity is greater than the alpha value (0.05). It can be concluded that leader support, competence, and organizational commitment have a relationship linear with employee performance, thus fulfilling the assumption of linearity, then data analysis can be done using multiple linear regression models.

To assess whether the independent variable has a significant influence on the dependent variable or cannot be known from the results of the F test. The F Test results with the help of SPSS 20.0 can be seen in Table 2 below. From the table, it can be explained that Leader Support (X1) variable regression coefficient is positive 0.239, this shows that the Support Leader has a positive effect on organizational commitment. Judging from the number of significance where the sig value is $0.009<0.05$, it can be interpreted that the variable Leader Support (X1) has a significant effect on organizational commitment. The competence variable regression coefficient (X2) is positive 0.653 , this indicates Competence has a positive effect on organizational commitment. Judging from the number of significance where the sig value is $0,000<0,05$, it can be interpreted that the Competence variable (X2) has a significant effect on organizational commitment.

Table 2. Regression Analysis Results Variables of Leader Support and Competence for Organizational Commitment

\begin{tabular}{lccc}
\hline \multicolumn{1}{c}{ Variables } & $\begin{array}{c}\text { Standardized } \\
\text { Coefficient Beta }\end{array}$ & T & Sig. \\
\hline Leader Support $\left(\mathrm{X}_{1}\right)$ & 0,239 & 2,692 & 0,009 \\
Competence $\left(\mathrm{X}_{2}\right)$ & 0,653 & 7,368 & 0,000 \\
R Square $=0,687$ & & & \\
\hline
\end{tabular}

Source: Primary data processed, 2019

From Table 3 below, it can be explained that Leader Support (X1) variable regression coefficient is positive 0.201, this shows the Support Leader has a positive effect on employee performance. Judging from the number of significance where the value of sig $0.023<0.05$, it can be interpreted that the variable Leader Support (X1) has a significant effect on employee performance. The competence variable regression coefficient (X2) is positive 0.367, this indicates Competence has a positive effect on employee performance. Viewed from the number of significance where the sig value is $0.007<0.05$, it can be interpreted that the variable Competence (X2) has a significant effect on employee performance. The regression coefficient of Organizational commitment (Y1) variable is positive 0.402, this indicates Organizational commitment has a positive effect on employee performance. Viewed from the number of 
significance where the sig value is $0.001<0.05$, it can be interpreted that the Organizational commitment (Y1) variable has a significant effect on employee performance.

Table 3. Regression Analysis Results Variable Leader Support, Competence, and Organizational Commitment to Employee Performance

\begin{tabular}{lccc}
\hline \multicolumn{1}{c}{ Variable } & $\begin{array}{c}\text { Standardized } \\
\text { Coefficient Beta }\end{array}$ & T & Sig. \\
\hline Leader Support $\left(\mathrm{X}_{1}\right)$ & 0,201 & 2,339 & 0,023 \\
Competence $\left(\mathrm{X}_{2}\right)$ & 0,367 & 2,773 & 0,007 \\
Organizational Commitment $\left(\mathrm{Y}_{1}\right)$ & 0,402 & 3,400 & 0,001 \\
R Square $=0,813$ & & & \\
\hline
\end{tabular}

Source: Primary data processed, 2019

The value of the error that occurs in Competence, Leader Support for Organizational commitment in the sub-structure equation I is the Y Organizational commitment value of 0.559. If the error value is smaller or less than the standard $\mathrm{Y}$ division, then it shows that the equation used is good. The value of errors that occur in Organizational commitment, Support Leader, Competence, on employee performance in the sub-structure II equation is the value of $\mathrm{Y}$ employee performance of 0.432 . If the error value is smaller or less than the standard $\mathrm{Y}$ division, then it shows that the equation used is good.

Based on a partial test, the following conclutions can obtained The Leader Support (X1) variable regression coefficient is positive 0.239 , indicating that the Support Leader (XI) has a positive effect on Organizational commitment (Y1). When viewed from the number of significance where the sig value is $0.009<0.05$, it can be interpreted that the variable Leader Support (X1) has a positive and significant effect on organizational commitment. Leader Support (X1) variable regression coefficient is positive 0.201, this shows the Support Leader (X1) has a positive effect on employee performance (Y2). When viewed from the number of significance where the value of sig $0.023<0.05$, it can be interpreted that the variable Leader Support (X1) has a positive and significant effect on employee performance.

The competence variable regression coefficient (X2) has a positive value of 0.653 , this indicates Competence (X2) has a positive effect on Organizational commitment (Y1). When viewed from the number of significance where the sig value is $0,000<0,05$, it can be interpreted that the Competence variable (X2) has a positive and significant effect on organizational commitment. The competence variable (X2) regression coefficient is positive 0.367 , this indicates Competence (X2) has a positive effect on employee performance (Y2). When viewed from the number of significance where the sig value is $0.007<0.05$, it can be interpreted that the Competence variable (X2) has a positive and significant effect on employee performance. Organizational commitment (Y1) regression coefficient is positive 0.402 , this indicates Organizational commitment (Y1) has a positive effect on employee performance (Y2). When viewed from the number of significance where the sig value is $0.001<0.05$, it can be interpreted that the Organizational commitment variable (Y1) has a positive and significant effect on employee performance.

The contribution of Leader Support (X1) which directly affects Organizational commitment (Y1) is $(0.239) 2=0.057$ or $5.7 \%$. The contribution of Leader Support (X1) which directly affects employee performance (Y2) is $(0.201) 2=0.040$ or $4 \%$. Contribution of Competence (X2) which directly affects Organizational commitment (Y1) is $(0.653) 2=0.426$ or 42.6\%. Contribution of Competence (X2) which directly affects employee performance (Y2) is 
(0.367) $2=0.135$ or equal to $13.5 \%$. The contribution of Organizational commitment (Y1) which directly affects employee performance (Y2) is (0.402) $2=0.162$ or equal to $16.2 \%$. Contribution of Support Leader (X1) which indirectly affects employee performance (Y2) through Organizational commitment $(\mathrm{Y} 1)$ is $(0.239 \times 0.402 \times 0.201)=0.0193$ or equal to $1.93 \%$. Contribution of Competence (X2) which indirectly affects employee performance (Y2) through Organizational commitment $(\mathrm{Y} 1)$ is $(0.653 \times 0.402 \times 0.367)=0.0963$ or $9.63 \%$.

Table 4. Results of Research Hypothesis Testing

\begin{tabular}{|c|c|c|}
\hline & Hypothesis & Conclusion \\
\hline H1 & $\begin{array}{l}\text { Leaders support has a positive influence on the employee } \\
\text { commitment of Human Resources Development Agency in } \\
\text { West Kalimantan. }\end{array}$ & proven \\
\hline H2 & $\begin{array}{l}\text { Leaders support has a positive influence on the performance } \\
\text { of employees of the Human Resources Development } \\
\text { Agency in West Kalimantan }\end{array}$ & proven \\
\hline H3 & $\begin{array}{l}\text { Competence has a positive on the organizational } \\
\text { commitment of employees of Human Resources } \\
\text { Development Agency in West Kalimantan }\end{array}$ & proven \\
\hline H4 & $\begin{array}{l}\text { Competence has a positive influence on the performance of } \\
\text { employees of the Human Resources Development Agency } \\
\text { in West Kalimantan }\end{array}$ & proven \\
\hline H5 & $\begin{array}{l}\text { Organizational commitment has a positive influence on the } \\
\text { employee performance of Human Resources Development } \\
\text { Agency in West Kalimantan }\end{array}$ & proven \\
\hline
\end{tabular}

Thus the results of path analysis testing for sub-structure I and sub-structure II can answer the research hypothesis and conclusions the results of the research hypothesis testing can be seen in Table 4 .

\section{A leader's support has a positive and significant influence on the employee commitment of the Human Resources Development Agency in West Kalimantan (H1).}

Based on the results of testing, the hypothesis that leaders support has a positive and significant effect on organizational commitment can be empirically proven. The results of this study support previous research that shows a positive effect of superior support for organizational commitment. Leaders support is the extent to which employers encourage participation in training, innovation, and knowledge acquisition and provide recognition to employees involved in activities. Leaders support produces a feeling that is mandatory for employees to help the organization achieve its goals, increase commitment to the organization and hope that high performance will be noted and valued. A leader's support also produces a feeling of obligation for employees to maintain the welfare of the organization manifested in the form of actions that can help the organization achieve its goals (Anang, 2016).

Organizational commitment can be formed from how much employees feel comfortable in their work environment which includes the possibility of employees developing and the availability of opportunities to use the skills or knowledge they have, the opportunity to be directly involved in decision making, rewards that meet the needs of employees according to their standard of living and wage standards and the availability of a conducive working environment, including the establishment of working hours, regulations that apply leadership and the physical environment (Supriyadi, 2010; Sulaefi, 2017). 
From this explanation, it can be concluded that the higher the suitability between a leader's support and their members, it will increase organizational commitment to employees of the Human Resources Development Agency in West Kalimantan. This situation is due to the suitability of characteristics between individuals with the values of a leader's support for the Human Resource Development Agency in West Kalimantan.

\section{A leader's support has a positive and significant influence on the performance of employees of the Human Resources Development Agency in West Kalimantan. (H2)}

Based on the results of testing, the hypothesis that leaders support has a positive and significant effect on employee performance can be empirically proven. The results of this study support research that also concludes that the leader's support has a significant influence on employee performance. A leader's support for employees can be demonstrated through the concern of superiors in providing advice and encouragement to take part in training that can improve the performance of the employees themselves. Besides, it also gives encouragement and participates in the process of training, innovation, and the acquisition of knowledge to employees is also considered necessary to create a sense of employee trust in superiors. And the last is to give recognition to the employees involved in the activity.

Recognition can be in the form of recognition of good employee performance and poor performance. Good performance will get recognition in the form of rewards from superiors, while poor performance will get punishment from superiors. This will spur all employees to compete in improving their performance (Prabu, 2016; Ismail et al., 2017). From this explanation, it can be concluded that the suitability of the leader's support desired by the employee turns out to have the ability to improve the performance of employees of the Human Resources Development Agency in West Kalimantan.

Competence has a positive and significant effect on the organizational commitment of employees of the Human Resources Development Agency in West Kalimantan (H3).

Based on the results of testing, the hypothesis that competency has a positive and significant effect on organizational commitment can be proven empirically. The results of this study support the results of studies that have been carried out that employees who have a strong commitment to the organization will automatically commit to their work or high employee competencies directly proportional to the commitment of employees in carrying out their work and the organization where they work.

As explained Ismail et al. (2017) that competence is the basic foundation of people's characteristics and indicates how to behave or think, equate situations, and support for a long period. Employee competency can be seen through strong employee motives that result in encouraging, directing and choosing behavior towards certain actions or goals. Besides, the nature of employees also influences the situation and information consistently. Competent employees must also have a strong self-concept with confidence and have confidence that it can always be effective, in every situation. Knowledge is information that people have in a specific field, knowledge is a complex competency, scores on knowledge tests often fail to predict work performance because they fail to measure knowledge and skills in ways that are used in work. And finally, employees must have the skills to do certain physical or mental tasks. mental competence or cognitive skills including analytical and conceptual thinking. 
From this explanation, it can be concluded that the higher the competency of employees, the higher the commitment of the employees of the Human Resources Development Agency in West Kalimantan. This situation is due to the empowerment and improvement of individual competencies of employees of the Human Resources Development Agency in West Kalimantan.

\section{Competence has a positive and significant influence on the performance of employees of the Human Resources Development Agency in West Kalimantan (H4).}

Asked on the results of testing, the hypothesis which states that competence has a positive and significant effect on employee performance can be proven empirically. The results of this study support research that states that competence has a positive and significant effect on employee performance (Sulaefi, 2017). According to Arifin et al. (2015), Competencies show the characteristics of the knowledge and skills possessed or needed by each individual that enables them to carry out their duties and responsibilities effectively and improve professional quality standards in their work. The higher professional quality standards in their work directly improve the performance of employees. What people do at work at various levels and specify the standards of each level, identify the characteristics of knowledge and skills needed by individuals that enable them to carry out their duties and responsibilities effectively in achieving professional quality standards at work (Rokhman et al., 2011). From this explanation, it can be concluded that the higher the competency turns out to be able to encourage the improvement of the performance of employees of the Human Resources Development Agency in West Kalimantan.

\section{Organizational commitment has a positive and significant influence on the employee performance of the Human Resources Development Agency in West Kalimantan (H5).}

Based on the results of testing, the hypothesis states that organizational commitment has a positive and significant effect on employee performance can be proven empirically. The results of this test support the results of the research that has been done. But in other studies, organizational commitment is considered not to have a significant effect on employee performance (Ismail et al., 2017; Emulti, 2013). From this explanation, it can be concluded that Employee organizational commitment has an influence that can improve the performance of employees of the Human Resources Development Agency in West Kalimantan.

\section{CONCLUSION}

From the results of the research and discussion in the previous chapter, it was concluded that there was a significant influence between leaders' support, competence, organizational commitment, and employee performance of the Human Resource Development Agency in West Kalimantan, for more details, the following conclusions can be seen. There is an influence of leader support on organizational commitment of employees of the Human Resource Development Agency in West Kalimantan. It can be proven empirically that the higher the suitability between the leader's support and its members, it will increase organizational commitment to employees.

There is the influence of leaders' support on the performance of employees of the Human Resources Development Agency in West Kalimantan. This means that the suitability of leaders' support with its members can improve employee performance. There is an influence of competence on organizational commitment of employees of the Human Resource Development in West Kalimantan. This is the higher competence of employees, the higher the commitment of 
employees of the human resource development in West Kalimantan. There is the influence of competence on the performance of employees of the Human Resource Development Agency in West Kalimantan. This means that higher competence turns out to be able to encourage improvement in employee performance. There is an organizational influence on the performance of employees of the Human Resources Development Agency in West Kalimantan. This means that the organizational commitment of employees gives a very large influence and fairness to improve employee performance.

Based on the conclusions and implications described above, the researcher will then submit many recommendations that are considered relevant to the results of the study. The recommendations include the following In the future, superiors will provide opportunities for all employees to improve their knowledge and skills so that they have integrity in their work. Bosses must always encourage their employees to master their work so they have professionalism at work. Bosses must be able to provide encouragement and enthusiasm to their employees to always work with other employees and can form a solid teamwork so that they can have synergy at work. Towards the Human Resources Development Agency in West Kalimantan employees must be able to increase their full responsibility for the work they are responsible for, must be able to cooperate with other employees, must immediately be able to adjust their work and environment, even if they are newly transferred or newly appointed as an employee, it aims to provide the best service. Employees should improve the quality of performance again by making it a habit to work effectively and efficiently or on time and in an appropriate manner. Employees should maintain, develop and improve the skills they have, as well as maintaining the conditions of the work environment that are achieved well.

\section{REFERENCES}

Anang, K. (2016). Pengaruh Persepsi Keadilan Distributif pada Penilaian Kinerja terhadap Kinerja Karyawan yang Dimediasi oleh Kepuasan Penilaian Kinerja di PT. Dok dan Perkapalan Surabaya. Jurnal Ekonomi, Bisnis Dan Kewirausahaan, 5(1), 1-23. https://www.researchgate.net/publication/322857216_Pengaruh_Persepsi_Keadilan_Dist ributif_pada_Penilaian_Kinerja_Terhadap_Kinerja_Karyawan_yang_Dimediasi_oleh_K epuasan_Penilaian_Kinerja_di_PT_Dok_dan_Perkapalan_Surabaya

Arifin, Z., Firmansyah, \& Fontana, A. (2015). The Determinant Factors of Technology Adoption for Improving Firm's Performance: An Empirical Research of Indonesia's Electricity Company. Gadjah Mada International Journal of Business, 18(3), 237-261. https://jurnal.ugm.ac.id/gamaijb/article/view/16898

Brahmana, R, K., Brahmana, R, K., \& Theresa. C. F. H. (2018). Training and Development Policy, Corporate Governance, and Firm Performance. Gadjah Mada International $\begin{array}{llll}\text { Journal of } & \text { Business, }\end{array}$ https://jurnal.ugm.ac.id/gamaijb/article/view/12995/20862

Cohen, D., Angela, K., \& Leung, Y. (2009). The Hard Embodyment of Culture. European Journal of Social Psychology, 39 (1), 61-65. http://doi.org/10.1002/ejsp.671

Elmuti (2013) Impact of Internet Added Self-Management Teams on Quality of Work-Life and Performance. https://journals.sagepub.com/doi/full/10.1177/1046496417710500 
Hendri, M. I., \& Ramadhania. (2010). Aplikasi TQM pada Manajemen Perguruan Tinggi: Sudut Pandang Kepemimpinan, Komitmen Organisasional dan Manajemen SDM. Jurnal Ekonomi, Bisnis dan Kewirausahaan, 1(2), 116-128. https://media.neliti.com/media/publications/10513 - ID - aplikasi - tqm - pada manajemen-perguruan-tinggi-sudut-pandang-kepemimpinan-komitmen.pdf

Ismail, D., Alam, S, S., \& Roshanti, bt A, H. (2017). Trust, Commitment, and Competitive Advantage in Export Performance of SMEs. Gadjah Mada International Journal of Business, 19(1), 1-18. https://jurnal.ugm.ac.id/gamaijb/article/view/22680

Krysik, J. L., \& Finn, J. (2010). Research for effective social work (2nd ed.). Philadelphia: Taylor and Francis.

Mahmud, S. H., \& Schölmerich, A. (2011). Acculturation and Life Satisfaction: Immigrants in Germany. Psychology Research, 1(4), 271-286. https://pdfs.semanticscholar.org/067e/3b569d5dd4f4437c25fb11075552cf06b391.pdf

Mailisa, Y., Hendri, M. I., \& Fauzan, R. (2016). Pengaruh Iklim Organisasi dan Kemampuan Kerja terhadap Komitmen Organisasional dan Dampaknya pada Kinerja Pegawai DISPERINDAGKOP dan UKM Kota Pontianak. Jurnal Ekonomi, Bisnis dan Kewirausahaan, 5(3), 198-215. http://jurnal.untan.ac.id/index.php/JJ/article/view/19081

Michell. D., Steward, \& Bruce, R. L (2009). A Comprehensive Analysis of Marketing Journal Rankings, Journal of Marketing Education, 32(1), 75-92. http://doi.org/10.1177/0273475309344804

Pella, M, D, A., Sumarman, U., Arief, D., \& Kirbradoko (2013). Factors Affecting Poor Strategy Implementation. Gadjah Mada, International Journal of Business, 15. https://jurnal.ugm.ac.id/gamaijb/article/view/5702

Prabu, D. T. W. (2016). Pengaruh Penghargaan dan Motivasi terhadap Kinerja Karyawan (Studi pada Divisi Penjualan PT. United Motors Center Suzuki Ahmad Yani, Surabaya). Jurnal Ekonomi Bisnis dan Kewirausahaan, 5(2), 104-117. http://jurnal.untan.ac.id/index.php/JJ/article/download/17144/14635

Ristyawan, M. R. (2016). Analysis of Restructuring Strategy of PT Indofood Sukses Makmur Tbk in Developing Company Life. Jurnal Ekonomi Bisnis dan Kewirausahaan, 5(1), 46-53. http://jurnal.untan.ac.id/index.php/JJ/article/download/16182/14094

Robbins, S. (2016). Organizational Behavior (D. H. Pujoatmoko, Ed.). Jakarta: PT. Prenhaltindo.

Rokhman, W., Rivai, H., \& Abidin, A. (2011). An Examination of the Mediating Effect of Islamic Work Ethic on the Relationships between Transformational Leadership and Work Outcomes. Gadjah Mada International Journal of Business, 13(2), 125-142. https://jurnal.ugm.ac.id/gamaijb/article/view/5487

Sulaefi. (2017). Pengaruh Keadilan Distributif dan Prosedural Kompensasi terhadap Kepuasan Kerja dan Kinerja Perawat di RSU DR. H. RM. SOESELO, di Slawi Kabupaten Tegal Jawa Tengah. Jurnal Ekonomi Bisnis dan Kewirausahaan, 6(1), 18-29. http://jurnal.untan.ac.id/index.php/JJ/article/view/20723

Supriyadi. (2010). Commitment, The Moderating Effect of Procedural Justice on The Effectiveness of The Balanced Scorecard in Improving Managerial Performance Through Organizational. Gadjah Mada International Journal of Business, 12(3), 415434.https://www.researchgate.net/publication/287872265_The_Moderating_Effect_of_P rocedural_Justice_on_the_Effectiveness_of_the_Balanced_Scorecard_in_Improving_Ma nagerial_Performance_through_Organizational_Commitment 
Waldan, R (2017). Quality of Work Life sebagai Solusi Peningkatan Kinerja Karyawan dalam Perspektif Islam. Jurnal Al-Hikmah, 12(2), 29-50. http://jurnaliainpontianak.or.id/index.php/alhikmah/article/view/1080/549

Waldan, R (2019). Pengantar Manajemen. Pontianak: IAIN Press.

Wheeler, R. M., Foster, J. W., \& Hapburn, K. W. (2013). The Experiences of Internationally Educated Nurses in the Southeastern United States of America. Educated Nurses in the Southeastern United States of America, 60(3), 397-404. https://onlinelibrary.wiley.com/doi/abs/10.1111/inr.12023

Yustina, T. V. (2018). Does Work-Family Conflict Affect Auditor's Performance? Examining the Mediating Roles of Emotional Exhaustion and Job Satisfaction. Gadjah Mada International Journal of Business, 20(1), 89-111. https://jurnal.ugm.ac.id/gamaijb/article/view/26302 